\title{
Energy Values and Estimation of Power Generation Potentials of Some Non- woody Biomass Species
}

Authors: M. Kumar ${ }^{\text {a }}$ S. K. Patel ${ }^{\text {b }}$
Affiliations: ${ }^{a}$ Department of Metallurgical and Materials Engineering, National Institute of Technology, Rourkela, India
${ }^{\mathrm{b}}$ Department of Mechanical Engineering, National Institute of Technology, Rourkela, India

Energy Sources, Part A: Recovery, Utilization, and Environmental Effects, Volume 30, Issue 8 May 2008 , pages $765-773$

http://dx.doi.org/10.1080/15567030701436206

Archived in Dspace@nitr http://dspace.nitrkl.ac.in/dspace 


\title{
ENERGY VALUES AND ESTIMATION OF POWER GENERATION POTENTIALS OF SOME NON-WOODY BIOMASS SPECIES
}

\author{
M. Kumar and S. K. Patel ${ }^{*}$ \\ Department of Metallurgical and Materials Engineering \\ * Department of Mechanical Engineering \\ National Institute of Technology \\ Rourkela-769 008, India
}

\begin{abstract}
In view of high energy potentials in non-woody biomass species and an increasing interest in their utilization for power generation, an attempt has been made in this study to assess the proximate analysis and energy content of different components of Ocimum canum and Tridax procumbens biomass species ( both nonwoody), and their impact on power generation and land requirement for energy plantations. The net energy content in Ocimum canum was found to be slightly higher than that in Tridax procumbens. In spite of having higher ash contents, the barks from both the plant species exhibited higher calorific values, The results have shown that approximately 650 and 1270 hectares of land are required to generate 20,000 kWh/day electricity from Ocimum canum and Tridax procumbens biomass species. Coal samples, obtained from six different local mines, were also examined for their qualities and the results were compared with those of studied biomass materials. This comparison reveals much higher power output with negligible emission of suspended particulate matters (SPM) from biomass materials.

(Keywords : Analysis, electricity generation, energy content, non-woody biomass species)
\end{abstract}




\section{INTRODUCTION}

In view of fast depletion of fossil fuel resources for power generation and growing concern over the environmental degradation caused by conventional power plants, electricity generation from biomass is becoming attractive throughout the world. Sustainable production and utilization of biomass in power generation can solve the vital issues of atmospheric pollution, energy crisis, wasteland development, rural employment generation and power transmission losses. Thus, the development of biomass-based power generation systems is thought to be favourable for majority of the developing nations including India. Unlike other renewables, biomass materials, predried upto about $15 \%$ moisture, can be stored for a considerable period of time without any difficulty (Gupta, 2003). Besides electricity supply to the national grids, biomass offers tremendous opportunities for decentralized power generation in rural areas at or near the points of use and thus can make villagers/ small industries self dependent in respect of their power requirements. Literature (Indian energy sector, 2000) reveals that the decentralized power generation systems reduce peaking loads and cost of maintenance of transmission and distribution networks.

For exploitation of biomass species in electricity generation, characterization of their various properties like energy values, chemical compositions, reactivities towards oxygen, bulk densities, etc. is essential. The present paper deals with the studies on proximate analysis and energy values of different components of Ocimum canum ( local name : Bantulsi ) and Tridax procumbens ( local name : Vaishlyakarani) biomass species ( non-woody and non-fodder) and their impact on electricity generation. Till recently, these biomass species have no commercial value and are under-exploited. 
However, they have several advantages as fuel crops. They are fast growing and reaches maturity in two years only. They can grow on poor and semi-desert land surviving with relatively little water.

\section{Biomass Potential in Electricity Generation}

Biomass resources are potentially the world's largest and most sustainable energy source for power generation in the $21^{\text {st }}$ century ( Hall \& Rao, 1999). Table 1 indicates that the annual sustainable world-wide biomass energy potential is about 104 EJ/a ( Parikka, 2003 ). The share of non-woody biomass is about 60\% ( 62 EJ/a approx.). Large potentials of non-woody biomass are available in Latin America, Africa and Asia. The total potential of non-woody and non-fodder biomass available for energy in India was estimated to be 325 Mt (472 PJ ) in 1996-97, and the proposed value for 2010 is 450 Mt ( 656 PJ ) ( Ravindranath etal., 2005 ). Table 1 clearly indicates that in most parts of the world, the current biomass use is much below the available potential except Asia. Hence, an increased biomass use, non-woody in particular, in electricity generation is possible. The greatest growth of biomass-based power plants is expected to occur in Asia and Latin America.

The world-wide estimated potentials of various types of renewable energy sources in electricity generation have been projected in Fig. 1 ( Renewable energy statistics, 2006 ). As shown in Fig. 1, the estimated global electricity generation capacity of biomass( about 11,000 Twh ) is greater than other renewable energy sources. The estimated power generation potentials of renewable energy sources in India have been outlined in Table 2 ( Renewable energy statistics, 2005 ). It is fairly 
clear from Fig.1 and Table 2 that the power generation potential of biomass is considerably greater in the world including India

\section{Biomass - A Source of Power Generation in Small-Scale Industries.}

In India, there are over 11 million small-scale registered industrial units that provide employment to more than 27 million people ( Gupta, 2006 ). They contribute to $40 \%$ of the country's industrial production and $34 \%$ of exports. A significant number of these units require large quantities of electrical energy. The high cost of supply, which is mostly erratic and unreliable on account of scheduled / unscheduled power cuts, drives industries to invest in captive power generation. As fossil fuels are limited and polluting, such demand provides an attractive platform to renewable for providing alternative energy solutions to industrial and commercial establishments, particularly small and medium enterprises. Biomass energy systems can be deployed to meet power requirement in industries. Such power generation will help industries in becoming selfreliant and relieve pressure on fossil fuels.

The captive biomass-based energy units having capacity ranging from about $100 \mathrm{KW}$ to few MW can be set-up by an industrial unit. In general, combustion-based systems are suited for MW-scale projects, whereas gasifiers are appropriate for small and decentralized power projects upto $1 \mathrm{MW}$ capacity. In addition to electricity, the bio-power plant is also likely to produce activated carbon ( a valuable product) that further offsets the operating cost of the plant. 


\section{Use of Biomass - A Remedy to Combat Pollution Emissions from Power Industries}

Sulphur oxides ( $\left.\mathrm{SO}_{\mathrm{x}}\right)$, nitrogen oxides $\left(\mathrm{NO}_{\mathrm{x}}\right)$, suspended particulate matters (SPM) and carbon dioxide are considered to be the basic pollutants emitted from thermal power plants. All these pollutants have unfavourable effects upon environment and social welfare. Various authors ( Kalika and Frant, 1999 ) write that the basic causes of acid rain are the $\mathrm{SO}_{\mathrm{x}}$ and $\mathrm{NO}_{\mathrm{x}}$ pollutants, while global warming is due to $\mathrm{CO}_{2}$ emission.

Since all green plants use $\mathrm{CO}_{2}$ for their growth, plantation of biomass species for electricity generation may be an effective way to slow the build-up of $\mathrm{CO}_{2}$ in the atmosphere. Biomass is practically free from sulphur, nitrogen and heavy metals ( $\mathrm{Hg}$, etc.), and has much lower ash content ( 1-3 wt.\% ) than coal ( Kumar and Gupta,1993 ). Hence, unlike fossil fuels, biomass use in electricity generation is not likely to pollute the atmosphere with $\mathrm{SO}_{\mathrm{x}}, \mathrm{NO}_{\mathrm{x}}$, SPM, etc..

\section{Planning of the Power Generation Structure}

In planning the electricity generation from biomass on decentralized basis, the following points should be taken into account:

- Kind, quality, quantity, feasibility of transportation and storage, sustainability and cost of biomass to be used

- Level of customer demand

- Method and cost of biomass drying

- Method of electricity generation and its economic viability

- Costs and qualities of locally available fossil fuels 


\section{EXPERIMENTAL}

\section{Materials Collection}

In this study, Ocimum canum and Tridax procumbens shrubaceous biomass species were collected from the local area and their components were removed separately and dried under sunlight for about a month. Non-coking coal samples from six different local coal mines ( being considered for electricity generation ) were also collected for study. The air-dried biomass and coal samples were crushed into powders and then processed for their proximate analysis and calorific value determination.

\section{Proximate Analysis and Calorific Value Determination}

Analyses for moisture, volatile matter, ash and fixed carbon contents were carried out on samples ground to -72 mesh size by standard methods ( IS :1350, 1969 ). The calorific values of the above ground samples were measured by Bomb calorimeter ( Agrawal and Jain, 1980).

\section{RESULTS AND DISCUSSION}

\section{Proximate Analyses and Calorific Values of Plant Components}

Freshly felled plant components contain a large amount of free moisture, which must be removed to decrease the transportation cost and increase the calorific value. In the plant species selected for the present study, the time required to bring their moisture contents into equilibrium with that of the atmosphere was found to be in the range 2-2.5 weeks during the summer season ( temperature : $37-42^{0} \mathrm{C}$ and humidity : 10 $25 \%)$. 
The proximate analyses and calorific values of different components of Ocimum canum and Tridax procumbens plant species are presented in Table 3. It can be seen that both the plant species have approximately the same proximate analysis results for their components, whereas the calorific values of their stumps and barks differed appreciably. It is interesting to note that in both the plant species, the bark exhibited the highest calorific value, followed by branch, leaf and stump respectively. The results ( Table 3) also indicate that the calorific values of bark and stump of Ocimum canum are higher than those of the same components of Tridax procumbens. As evidenced by Table 3, barks and leaves from both the plant species were found to have higher ash contents than other components.

The major chemical constituents affecting the calorific values of carbonaceous materials are carbon and hydrogen. The above variation in calorific values of plant components is obviously related to the combined effects of their carbon and hydrogen contents.

\section{Estimation of Decentralized Power Generation Structure in Rural Areas}

For the estimation of power generation to meet the electricity requirements of villages, a group of 10-15 villages consisting of 3000 families may be considered, for which one power station could be planned. The power requirement for lighting and domestic work in these villages may be $6000 \mathrm{kWh} /$ day. An additional 14,000 kWh/day (approx.) may be required for agriculture (irrigation) and small-scale industries situated in a group of villages. Thus, a power plant should be capable of generating 20,000 $\mathrm{kWh} /$ day $\left(73 \times 10^{5} \mathrm{kWh} /\right.$ year) for a group of $10-15$ villages. 
Table 4 presents the design of energy plantations from Ocimum canum and Tridax procumbens biomass species for a power plant having a capacity of 20,000 kWh/day. The results (Table 4) show that in order to meet the yearly electricity requirement of the order of $73 \times 10^{5} \mathrm{kWh}$ for a group of 10-15 villages, 200 ha (in case of use of Ocimum canum) or 408 ha ( in case of use of Tridax procumbens) of land ( covered with biomass) should always be ready for harvesting. In order to have perpetual generation of electricity, the entire energy plantation area is suggested to be divided into three blocks, each comprising an area of about 200 ha ( for Ocimum canum) or 408 ha ( for Tridax procumbens). In the first year, the first block should be planted, followed by second and third blocks in successive years. When plantations are completed in third block, the first block plants would be 2 years old and ready for harvesting. Considering the requirement of approximately 50 ha of land for making roads, residential quarters, and establishment of the power plant, the net requirement of land would be 650 ha for Ocimum canum or 1274 ha for Tridax procumbens. The higher land area requirement in case of use of Tridax procumbens is due to its relatively lower biomass yield.

\section{Proximate Analyses and Energy Values of Some Coals and Comparisons with Biomass Materials}

Six different types of non-coking coals, to be exploited for electricity generation in Orissa (India), were tested for their proximate analysis and calorific values, and the results obtained have been presented in Table 5. It can be seen from this table that the siding coal has the highest calorific value, followed by Yeurve, Jagannath, Kalinga, Lakhanpur and Hingola coal. The ash contents in these coals are much higher (range : 
$39-60 \%)$ and they are expected to pollute the environment heavily with SPM (suspended particulate matter). This is a big problem and the solution is not easy.

Comparison of data listed in Tables 3 and 5 indicates that in contrast to coals included in the present study, Ocimum canum and Tridax procumbens, biomass materials have significantly higher calorific values and much lower ash contents, which is a definite advantage over fossil coals. It is thus obvious that these biomass materials will result in higher power output in the plant with negligible emission of suspended particulate matters (SPM).

\section{SUGGESTIONS}

( i ) Important knowledge and new technical information related to sustainable biomass production and its efficient utilization need to be synthesized and transferred to the shareholders.

( ii ) The economic, social and environmental aspects of biomass production and utilization systems must be examined.

( iii ) Interdisciplinary research works on production, conversion and utilization of biomass need to be encouraged.

( iv ) Energy cultivation in wasteland, and a system for successful collection and transportation of biomass materials to the power plants need to be developed.

( v ) Village energy committees may be set-up to look after and ensure the sustainability of biomass-based power plants in rural areas. 
( vi ) Awareness among the people about the various aspects of biomass-based power plants, need for energy plantations, etc. should be created.

( vii )Financial assistance from the government need to be provided to encourage the development of such projects.

\section{CONCLUSIONS}

The main findings derived from the present study are as follows:

1. Both the plant species ( Ocimum canum and Tridax procumbens) showed nearly the same proximate analysis results for their components, the ash contents being more in their barks and leaves.

2. Both the plant species showed highest energy values for their barks, followed by branch, leaf and stump respectively.

3. In comparison to Tridax procumbens, somewhat higher energy value has been observed in Ocimum canum biomass species.

4. Calculation results have demonstrated that nearly 650 and 1274 hectares of land would be required for continuous generation of 20,000 kWh electricity per day from Ocimum canum and Tridax procumbens biomass species.

5. In contrast to locally available coals, both the studied plant species showed higher energy values and much lower ash contents. This indicates higher power generation potential in biomass than coals.

6. The present study could be useful in the exploitation of non-woody biomass species for power generation. 


\section{REFERENCES}

Biomass: Versatile Source of Energy, 2000. Indian Energy Sector; Newswatch Tracks.

Hall, D.O., and K. K. Rao. 1999. Photosynthesis, 6 ${ }^{\text {th }}$ Edn. , Studies in Biology, Cambridge University press.

Parikka, M. 2004. Global biomass fuel resources. Biomass and Bioenergy 27: 613620.

Ravindranath, N. H., H. I. Somashekar, M. S. Nagaraja, P. Sudha, G. Sangeetha, S. C. Bhattacharya, and P. Abdul Salam. 2005. Assessment of sustainable non-plantation biomass resources potential for energy in India. Biomass and Bioenergy 29: 178-190.

Renewable Energy Statistics : Renewable energy at a glance in the world, 2006. Akshay Urja 2: 48.

Renewable Energy Statistics: Renewable energy at a glance in India, 2005. Akshay Urja 1: 48.

Gupta, A. K. 2006. Renewable energy in industry. Akshay Urja 2: 13-15.

Kumar. M. , and R. C. Gupta. 1992. Properties of acacia and eucalyptus woods. Jl. of Materials Science Letters 11: 1439-1440.

Kalika, V. , and S. Frant. 1999. Environmental aspects of power generation. Energy Sources 21: 687-704.

Bureau of Indian Standards. 1969. IS: 1350, Part I. Methods of tests for coal and coke, p.3, New Delhi.

Agrawal, B. C., and S. P. Jain. 1980. A Text-Book of Metallurgical Analysis, $3^{\text {rd }}$ Edn., p.277. Khanna Publishers, New Delhi. 
Table 1

Biomass energy potentials and current use in different regions ( Parikka, 2003 )

\begin{tabular}{|l|c|c|c|}
\hline \multirow{2}{*}{ Region } & \multicolumn{2}{|c|}{$\begin{array}{c}\text { Biomass energy potentials } \\
\text { (EJ/a) }\end{array}$} & \multirow{2}{*}{ Use \% ) } \\
\cline { 2 - 3 } & Woody & Non-woody & 16 \\
\hline North America & 12.8 & 7.1 & 12 \\
\hline Latin America & 5.9 & 15.6 & 108 \\
\hline Asia & 7.7 & 13.7 & 39 \\
\hline Africa & 5.4 & 16.0 & 22 \\
\hline Europe & 4.0 & 4.9 & 5 \\
\hline Former USSR & 5.4 & 4.6 & 38 \\
\hline Middle East & 0.4 & 0.3 & 72.2 \\
\hline World & 41.6 & 62.2 & \\
\hline $\begin{array}{l}\text { Non - woody biomass = Energy crops + straw + others } \\
\text { ( EJ = 10 }{ }^{18} \mathrm{~J} \text { ) }\end{array}$ & \\
\hline
\end{tabular}

Table 2

Electricity generation potentials of renewable energy sources in India (Renewable energy statistics, 2005)

\begin{tabular}{|l|c|c|}
\hline \multicolumn{1}{|c|}{ Source } & $\begin{array}{c}\text { Estimated potential } \\
\text { (MW) }\end{array}$ & $\begin{array}{c}\text { Cumulative } \\
\text { installed capacity } \\
\text { (MW) }\end{array}$ \\
\hline Wind energy & 45,000 & $4,434.00$ \\
\hline Biomass energy & 16,000 & 376.00 \\
\hline Bagasse & 3,500 & 491.00 \\
\hline Small hydro (upto 25 MW) & 15,000 & $1,748.00$ \\
\hline Waste-to-energy & 2,700 & 45.76 \\
\hline Solar photovoltaic & $20 \mathrm{MW} / \mathrm{km}^{2}$ & 2.80 \\
\hline
\end{tabular}




\section{Table 3}

Proximate analysis and Calorific values of different components of Ocimum canum and Tridax procumbens shrub plants

\begin{tabular}{|c|c|c|c|c|}
\hline \multirow[t]{2}{*}{ Component } & \multicolumn{3}{|c|}{$\begin{array}{l}\text { Proximate analysis } \\
\text { ( wt. \%,dry basis) }\end{array}$} & \multirow{2}{*}{$\begin{array}{c}\text { Calorific } \\
\text { value } \\
\text { ( Kcal/kg,dry } \\
\text { basis) }\end{array}$} \\
\hline & $\begin{array}{l}\text { Volatile } \\
\text { matter }\end{array}$ & Ash & $\begin{array}{c}\text { Fixed } \\
\text { carbon }\end{array}$ & \\
\hline \multicolumn{5}{|c|}{ Ocimum canum } \\
\hline Stump & 75.67 & 3.37 & 20.96 & 5088 \\
\hline Branch & 75.80 & 3.82 & 20.38 & 5353 \\
\hline Leaf & 71.81 & 5.39 & 22.80 & 5141 \\
\hline Bark & 70.10 & 5.38 & 24.52 & 7095 \\
\hline \multicolumn{5}{|c|}{ Tridax procumbens } \\
\hline Stump & 75.15 & 3.15 & 21.70 & 4714 \\
\hline Branch & 76.82 & 2.92 & 20.26 & 5325 \\
\hline Leaf & 71.69 & 6.64 & 21.67 & 5169 \\
\hline Bark & 71.14 & 6.10 & 22.76 & 6850 \\
\hline
\end{tabular}


Table 4

Total energy contents and power generation structure from 18 months old (approx.) Ocimum canum and Tridax procumbens shrub plants

\begin{tabular}{|c|c|c|c|}
\hline Component & $\begin{array}{c}\text { Calorific value } \\
\text { (kcal/t, dry basis) }\end{array}$ & $\begin{array}{c}\text { Biomass * } \\
\text { production (t/ha, } \\
\text { dry basis) }\end{array}$ & $\begin{array}{c}\text { Energy value } \\
\text { (kcal/ha) }\end{array}$ \\
\hline
\end{tabular}

\section{Ocimum canum}

$\begin{array}{llll}\text { Stump } & 5088 \times 10^{3} & 8.03 & 40,857 \times 10^{3} \\ \text { Branch } & 5353 \times 10^{3} & 6.91 & 36,989 \times 10^{3} \\ \text { Leaf } & 5141 \times 10^{3} & 3.82 & 19,639 \times 10^{3} \\ \text { Bark } & 7095 \times 10^{3} & 3.60 & 25,542 \times 10^{3}\end{array}$

Total energy from one hectare of land $=(40,857+36,989+19,639+25,542) \times 10^{3}$

$$
=1,23,027 \times 10^{3} \mathrm{kcals}
$$

\section{Tridax procumbens}

$\begin{array}{llll}\text { Stump } & 4714 \times 10^{3} & 5.00 & 23,570 \times 10^{3} \\ \text { Branch } & 5325 \times 10^{3} & 2.75 & 14,644 \times 10^{3} \\ \text { Leaf } & 5169 \times 10^{3} & 2.85 & 14,732 \times 10^{3} \\ \text { Bark } & 6850 \times 10^{3} & 1.10 & 7535 \times 10^{3}\end{array}$

Total energy from one hectare of land $=(23,570+14,644+14,732+7535) \times 10^{3}$

$$
=60,481 \times 10^{3} \mathrm{kcals}
$$

* Data from field studies

Assumptions made in the power generation calculation are as follows:

(i ) Conversion efficiency of biomass fuelled thermal power plants $=30 \%$ 
( ii ) Overall efficiency of the thermal power plant $=85 \%$

The energy value of total utilizable Ocimum canum biomass obtained from one hectare of land at 30\% efficiency of power plant

$$
=1,23,027 \times 10^{3} \times 0.30 \mathrm{kcals}=36,908.1 \times 10^{3} \mathrm{kcals}=42,866.6 \mathrm{kWh}
$$

The energy value of total utilizable Tridax procumbens biomass obtained from one hectare of land at 30\% efficiency of power plant

$$
=60,481 \times 10^{3} \times 0.30 \mathrm{kcals}=18,144.3 \times 10^{3} \mathrm{kcals}=21,073.5 \mathrm{kWh}
$$

Power generation at $85 \%$ overall efficiency

(i ) From Ocimum canum $=42,866.6 \times 0.85=36,437 \mathrm{kWh} / \mathrm{ha}$

( ii ) From Tridax procumbens $=21,073.5 \times 0.85=17,913 \mathrm{kWh} / \mathrm{ha}$

Land required to supply electricity for the whole year

$$
\begin{aligned}
& =\frac{73 \times 10^{5}}{36437} \approx 200 \text { hectares ( for Ocimum canum plant ) } \\
= & \frac{73 \times 10^{5}}{17913} \approx 408 \text { hectares ( for Tridax procumbens plant ) }
\end{aligned}
$$

$\underline{\text { Table } 5}$

Proximate analysis and calorific values of non-coking coals obtained from different mines of Orissa (India)

\begin{tabular}{|l|c|c|c|c|}
\hline \multirow{2}{*}{\multicolumn{1}{|c|}{ Coal mine }} & \multicolumn{3}{|c|}{$\begin{array}{c}\text { Proximate analysis } \\
\text { ( wt.\%, dry basis) }\end{array}$} & \multirow{2}{*}{$\begin{array}{c}\text { Calorific value } \\
\text { (kcal/kg) dry basis }\end{array}$} \\
\cline { 2 - 4 } & $\begin{array}{c}\text { Volatile } \\
\text { matter }\end{array}$ & Ash & $\begin{array}{c}\text { Fixed } \\
\text { carbon }\end{array}$ & \\
\hline Lakhanpur & 21.21 & 52.24 & 26.55 & 3938 \\
\hline Siding & 30.62 & 44.30 & 25.08 & 4952 \\
\hline Hingola & 21.90 & 59.83 & 18.27 & 3355 \\
\hline Yeurve & 35.66 & 38.90 & 25.44 & 4682 \\
\hline Kalinga & 24.77 & 50.77 & 24.46 & 4237 \\
\hline Jagannath & 31.10 & 52.68 & 16.22 & 4660 \\
\hline
\end{tabular}




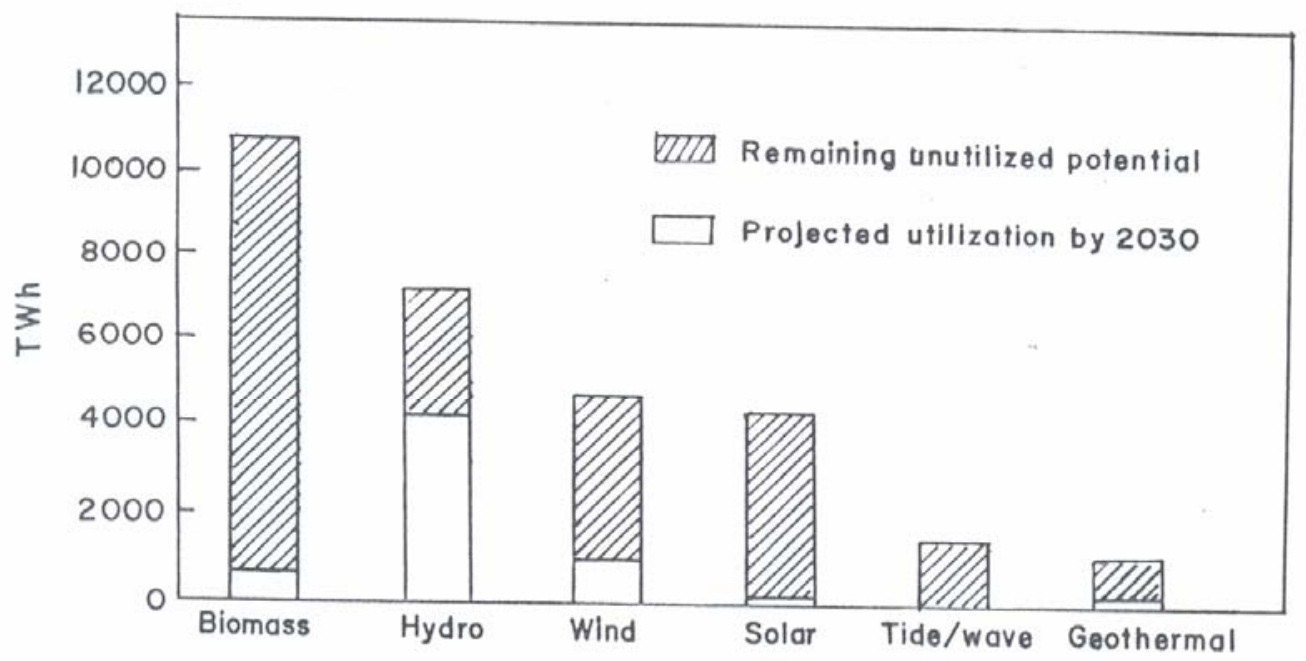

Fig.1 World Long-Term Renewable Energy potential for Electricity Geveration. 